\title{
Seasonal Differences in Taxonomic Diversity of Rotifer Communities in a Hungarian Lowland Oxbow Lake Exposed to Aquaculture Effluent
}

\author{
Flórián Tóth ${ }^{1,2,3, *}$, Katalin Zsuga ${ }^{4}$, Éva Kerepeczki ${ }^{1}{ }^{\circledR}$, László Berzi-Nagy ${ }^{1}$, László Körmöczi ${ }^{2}$ \\ and Gábor L. Lövei ${ }^{3}$ D \\ 1 Department of Hydrobiology, National Agricultural Research and Innovation Centre-Research Institute for \\ Fisheries and Aquaculture, 5540 Szarvas, Hungary; kerepeczki.eva@haki.naik.hu (É.K.); \\ berzi-nagy.laszlo@haki.naik.hu (L.B.-N.) \\ 2 Department of Ecology, Faculty of Science and Informatics, University of Szeged, 6720 Szeged, Hungary; \\ kormoczi@bio.u-szeged.hu \\ 3 Department of Agroecology, Aarhus University, Flakkebjerg Research Center, 4200 Slagelse, Denmark; \\ gabor.lovei@agro.au.dk \\ 4 Agrint Ltd., 2100 Gödöllő, Hungary; zsuga.katalin@gmail.com \\ * Correspondence: toth.florian@haki.naik.hu; Tel.: +36-66-515-300
}

Received: 30 March 2020; Accepted: 2 May 2020; Published: 5 May 2020

\begin{abstract}
With the intensification of aquaculture technologies, the amount of feed input and waste material is increasing, creating potentially negative impacts on freshwater habitats receiving effluent from such systems. Changes in biodiversity of zooplankton communities is often used to assess the effects of such impacts. Rotifers are suitable for bioindication of water quality due to their fast reaction to environmental changes. We examined seasonal changes in the diversity of rotifer communities along a $3.5 \mathrm{~km}$ section of the biggest oxbow lake in the Tisza River basin, Hungary, that received inflow from an intensive tank-based aquaculture farm. We detected a species-rich rotifer community with 26 species. Using the Rényi one-parameter diversity index families, we found that biodiversity increased away from the point of inflow in spring, but after a summer transition period the situation became partially reversed during autumn. At the beginning of the study period, the nutrient-rich effluent strengthened the dominance of common species, which decreased but did not disappear in summer. In autumn, the extra nutrient input delayed the decline of the rotifer community at the point of effluent.
\end{abstract}

Keywords: Rotifera; nutrient load; water quality; indication; Rényi diversity

\section{Introduction}

With growing human population, protein production by aquaculture has greatly increased, becoming the fastest growing animal husbandry sector in the world [1]. As aquaculture production is intensifying, the amount of fish feed input and the resulting waste, including organic matter, nutrients, and suspended solids, is also increasing [2]. These create potentially negative impacts on neighbouring habitats, especially the freshwater habitats receiving outflow from such systems [3].

Wetlands in general have suffered a great reduction in Europe during the 20th century [4], and many of the remaining ones, often even in protected areas, are under encroachment from aquaculture [5]. The river regulation at our study site, the Hungarian lowland, was the biggest such enterprise in Europe during the 19th century and has profoundly modified the lowland environment and water regime [6]. The regulation decreased the meandering of the Tisza River to enhance flood management. After completion, the Tisza became $457 \mathrm{~km}$ shorter, but the originally ignored negative ecological 
impacts soon became evident [7]. An unexpected side benefit was that many of the isolated meanders became oxbow lakes and developed into valuable wetland habitats. The Kákafok oxbow lake near to the settlements of Szarvas and Békésszentandrás, formed after the regulation of River Körös (a tributary of the Tisza River), is the largest of the Tisza watershed, and also represents significant natural value. It has a significant role in the formation of the characteristic landscape of the Körös River basin, and provides different anthropogenic utilization opportunities [8], which influence the composition of the aquatic communities.

The assessment of changes in the biodiversity of impacted habitats is an indispensable part of the analysis of anthropogenic effects. A complete inventory of all elements of biodiversity is rarely feasible, thus the selection of a suitable indicator group is an important decision. In water quality assessment, several planktonic organisms have been suggested as indicator groups Rotifers have been used for water quality assessment from New Zealand [9] to Ireland [10]. Several authors have used rotifers to indicate eutrophication [11-16] and saprobity [17,18], and to develop trophic state indices [19,20]. The microscopic size of rotifers contributes to their cosmopolitan and ubiquity distribution [21,22], although at a much lower level than previously thought [23]. They also have several endemisms with narrow biogeographical distribution [24,25]. Because of this, the communities of rotifers are often included in faunistic and ecological investigations. Rotifers play an important role as the basis of the food web of aquatic ecosystems, transferring energy from lower to higher trophic levels [26]. Rotifers are amongst the fastest growing of planktonic indicator groups [27], and thus their communities react quickly to physical, chemical and biological changes in water $[18,28,29]$.

Surveys of the zooplankton communities of the Tisza River began in the middle of the 20th century [30]. The research into the River Körös received some attention, [31,32] but the rotifers of oxbow lakes have been less investigated. A recent study [33] dealt with protected oxbow lakes nearby but left out the biggest, the Szarvas-Békésszentandrás (Kákafok) oxbow lake, because it is not under nature protection. A common feature of these studies is that they considered the individual water bodies to be homogeneous and only one or two samples per year were taken, providing information about the overall composition of the rotifer community. On the other hand, seasonal variations are also important, and these assessments did not explore the advantage that rotifers respond quickly to environmental changes.

The main goal of this article is to assess the cumulative effects of aquaculture effluent on the seasonal structure of rotifer communities in a spatially explicit manner and to describe the seasonal changes in rotifer communities along a $3.5 \mathrm{~km}$ long section of the Kákafok oxbow lake, at increasing distances from the point of effluent. For a synthetic analysis of diversity, we chose the Rényi one-parameter diversity index family [34]. We hypothesized that the effluent affects community composition but the effect is diluted as the distance from the inlet point increases. We expected that, under oligotrophic conditions, a generally species-rich community develops with low dominance, while there are fewer species with higher abundance under nutrient-rich conditions [35,36]. Consequently, our second hypothesis was that lower taxonomic diversity would be recorded near the inflow, while diversity would increase farther away from the point of inflow.

\section{Materials and Methods}

\subsection{Study Site}

The Kákafok oxbow lake located near Szarvas and Békésszentandrás ( $46^{\circ} 51^{\prime} 14.9^{\prime \prime} \mathrm{N}, 20^{\circ} 30^{\prime} 44.6^{\prime \prime}$ E) is the biggest protected oxbow lake of the River Tisza watershed. This water body is $29 \mathrm{~km}$ long, spreading over $207 \mathrm{ha}$, with an average depth of $2.2 \mathrm{~m}$, holding 4.5 million $\mathrm{m}^{3}$ of water [8]. The lake is semi-paleopotamonic with a possibility of supplementing or replacing water, pumping over from the parent river [37]. The oxbow lake was filled up at the beginning of the year and the water level lowered in late autumn. Between these two events, there was no significant water movement or flow, 
so we considered it as stagnant water, with no species influx possible during the year. The oxbow serves for storing inland excess and irrigation water as well as for various recreational activities [8].

Along a $3.5 \mathrm{~km}$ section, we selected five sampling points (K1-K5) (Figure 1) at different positions in relation to the combined inflow from a thermal water fish farm producing African catfish (Clarias gariepinus) and the experimental fish ponds of the Research Institute for Fisheries and Aquaculture, National Agricultural Research and Innovation Centre-(HAKI). No other source of contamination is known at this section of the oxbow lake. This inflow, located at site K1, was nutrient-rich, partly of geothermal origin, and before reaching the oxbow lake was treated by a wastewater-cleaning wetland system. During the treatment process, the thermal water from the catfish farm cooled down, so at the point of inflow no thermal pollution occurred. Further sampling points were selected based on the characteristics of the oxbow lake. Because there was no significant water flow, we only considered distance from inflow. The $\mathrm{K} 2$ point was at $500 \mathrm{~m}, \mathrm{~K} 3$ at $2.5 \mathrm{~km}$ (to avoid interference by a fish sampling operation), $\mathrm{K} 4$ at $3.0 \mathrm{~km}$ and $\mathrm{K} 5$ at $3.5 \mathrm{~km}$ from the influx point. The nutrient content of the water decreases away from the influx. In the year of the survey at the point of $\mathrm{K} 1$, the content of Total Nitrogen (TN) was $0.195-4.000 \mathrm{mg} / \mathrm{L}$, the Total Phosphorous (TP) from 0.053 to $0.468 \mathrm{mg} / \mathrm{L}$ and the Total Suspended Solids (TSS) from 13.14 to $41.10 \mathrm{mg} / \mathrm{L}$. These values at point K5 were the following: TN: $0.275-1.140 \mathrm{mg} / \mathrm{L}, \mathrm{TP}: 0.062-0.210 \mathrm{mg} / \mathrm{L}$ and TSS: 7.1-28.6 mg/L [38]. The yearly amount of the effluent of the catfish farm was about $330,500 \mathrm{~m}^{3}$ [39].

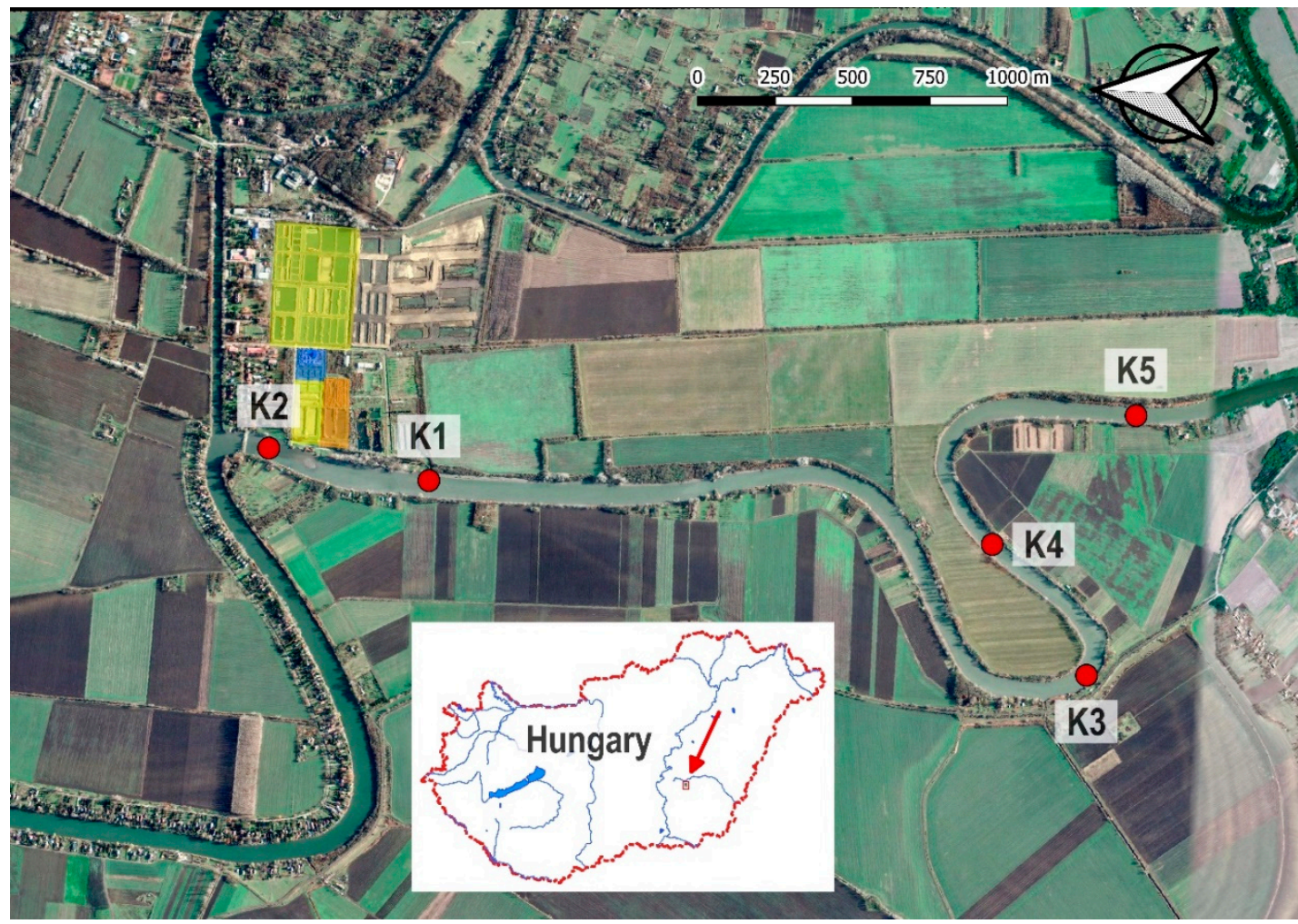

Figure 1. Situations of the sampling points (K1-K5) of the Kákafok oxbow lake in Hungary. The yellow squares indicate the experimental fish ponds of the Research Institute for Fisheries and Aquaculture (HAKI), the blue square indicates the African catfish farm and the orange one the artificial wetland water treatment system. The line left of point $\mathrm{K} 2$ indicates a bridge with limited through-flow, effectively blocking water mixing in that direction. Intensive fish sampling took place between points K1 and K3, which is why no sampling point was placed there. (Source: Google Earth). 


\subsection{Chemical Water Characteristics}

In the year of the survey, $1500 \mathrm{~mL}$ of effluent water from the African catfish farm was collected monthly and taken to the laboratory at the National Agricultural Research and Innovation Centre (NAIK) Research Institute of Irrigation and Water Management where TN [40] and TP [41] were measured by spectrophotometry, and TSS [42] by weight measurements. These water samples were collected from the outflow of the artificial wetland water treatment system.

\subsection{Zooplankton Sampling}

We sampled the rotifer community nine times (3 times/season: spring: 20 April 2016, 10 May 2016, 01 June 2016; summer: 29 June 2016, 21 July 2016, 10 August 2016; autumn: 30 August 2016, 21 September 2016, 24 October 2016) at each sampling point, when we took $50 \mathrm{~L}$ of water from $<50 \mathrm{~cm}$ below the surface, and filtered it using a $50 \mu \mathrm{m}$ mesh plankton net. The filtered samples $(100 \mathrm{~mL}$ were put into a $120 \mathrm{~mL}$ plastic bottle, preserved by adding formaldehyde ( $4 \%$ final concentration) and taken into the laboratory, where they were stored at $4{ }^{\circ} \mathrm{C}$ until identification. Zooplankton density was assessed using a 5-mL counting chamber. Rotifer identification was made under 40-125 $\times$ magnification, following standard keys $[43,44]$.

\subsection{Diversity Evaluation}

The analysis of rank-abundance curves was performed with the vegan [45] package in $\mathrm{R}$ [46]. Rank-abundance graphs were visualised in EXCEL [47,48]. To compare rotifer diversity among sample sites, we used the diversity ordering with the Rényi generalised entropy function (HR; Equation (1)) [34]:

$$
H R(\alpha)=\frac{1}{1-\alpha} \log \sum_{i=1}^{S} p_{i}^{\alpha}
$$

where $p_{i}$ is the relative abundance of the $i$-th species, $S$ is the total number of species in the sample, and $\alpha$ is the scale parameter which has no exact biological meaning.

The Rényi-function is a generalised entropy function, because at special values of the scale parameter $\alpha$, the value of the Rényi diversity will take the value of several frequently used entropy-based diversity indices (Table 1) [34,49]. In general, at low values of the scale parameter (close to 0) the Rényi index is sensitive to rare species, whereas with increasing $\alpha$, the diversity value will gradually be influenced more by the more abundant species [34]. Diversity profiles were calculated using the vegan [45] package in $\mathrm{R}$ [46].

Table 1. Special values of scale parameters $(\alpha)$ of the Rényi diversity.

\begin{tabular}{ccc}
\hline Scale Parameter $(\alpha)$ & Rényi Diversity (HR) \\
\hline 0 & logarithm of number of species & $\log S$ \\
$\lim _{\alpha \rightarrow 1}^{*}$ & Shannon diversity & $-\sum_{i=1}^{S} p_{i} \log \left(p_{i}\right)$ \\
2 & logarithm of inverse Simpson diversity & $\log \frac{1}{\sum_{i=1}^{S} p_{i}^{2}}$ \\
$\lim _{\alpha \rightarrow+\infty}$ & logarithm of Berger-Parker index & $\log \frac{1}{p_{\max }}$ \\
\hline
\end{tabular}

* Scale parameter cannot take the exact value of 1, but its limit as $\alpha$ tends to 1 .

\section{Results}

\subsection{Nutrient Input}

During the study period, an estimated $4200 \mathrm{~kg} \cdot \mathrm{y}^{-1}$ of nitrogen, $475 \mathrm{~kg} \cdot \mathrm{y}^{-1}$ of phosphorous and $5220 \mathrm{~kg} \cdot \mathrm{y}^{-1}$ of suspended solids were released into the oxbow lake from intensive aquaculture (Table 2). 
Table 2. The amount of nutrient entering the Kákafok oxbow lake.

\begin{tabular}{cccc}
\hline Season & Total Nitrogen $\mathbf{( k g )}$ & Total Phosphorus $\mathbf{( k g )}$ & Total Suspended Solids $\mathbf{( k g )}$ \\
\hline Spring & 1600 & 168 & 1135 \\
Summer & 830 & 120 & 1275 \\
Autumn & 1770 & 188 & 2810 \\
\hline Total & 4200 & 475 & 5220 \\
\hline
\end{tabular}

\subsection{Composition of the Rotifer Assemblage}

During the sampling period, 28 rotifer taxa were collected: 26 were identified to species level, and 2 additional ones to genus level (Table S1). The highest species richness (14 species) and density $\left(163,272 \mathrm{ind} \cdot \mathrm{m}^{-3}\right)$ were registered at the inlet point (K1) in the summer and the lowest values (2 species and $864 \mathrm{ind} \cdot \mathrm{m}^{-3}$ ) were found at the most distant point (K5) in autumn (Table S1). The most frequent and widespread species were Brachionus calyciflorus and B. leydigi; these were absent from only 2 sites. There were 5 singleton species, observed in only one sample. The most species-rich genus, Brachionus was represented by 10 species.

In spring, the most species-rich site was K5 (11 species), but this site had the lowest density (7560 ind $\left.\cdot \mathrm{m}^{-3}\right)$. The highest abundance $\left(140,472 \mathrm{ind} \cdot \mathrm{m}^{-3}\right)$ was found at K2. B. nilsoni and B. leydigi were most abundant at the point of inflow and at a distance of $0.5 \mathrm{~km}(\mathrm{~K} 2)$.

In summer, the highest species richness and density were observed at the inflow (K1 site). In summer, the abundance varied between 71,928 and 163,488 ind $\cdot \mathrm{m}^{-3}$ and was dominated by B.angularis and B. calyciflorus. The number of species varied between 7 (K5) and 14 (K1).

In autumn, the highest number of species (12) as well as individuals $\left(12,096 \mathrm{ind} \cdot \mathrm{m}^{-3}\right)$ were detected at $\mathrm{K} 1$, and the lowest ( 2 species and $864 \mathrm{ind} \cdot \mathrm{m}^{-3}$ ) at the most distant site, $\mathrm{K} 5$.

\subsection{Diversity and Diversity Ordering}

\subsubsection{Species Distributions}

The spring assemblages from $\mathrm{K} 1$ to $\mathrm{K} 5 \mathrm{had}$ a similar number of species (8-11), but the evenness increased with increasing distance from the inflow point (Figure 2). In summer, the species richness was the highest at the inflow. Considering the most frequent and the rarest species, $\mathrm{K} 1$ had the highest number of individuals but, in the case of the moderately common species (species rank: 3-10), K2, $\mathrm{K} 4, \mathrm{~K} 5$ sites showed higher diversity. In autumn, the assemblage at the inlet point (K1) was the most species-rich with a correspondingly high number of individuals. At K3-K5, the number of species and individuals were lower (Figure 2).
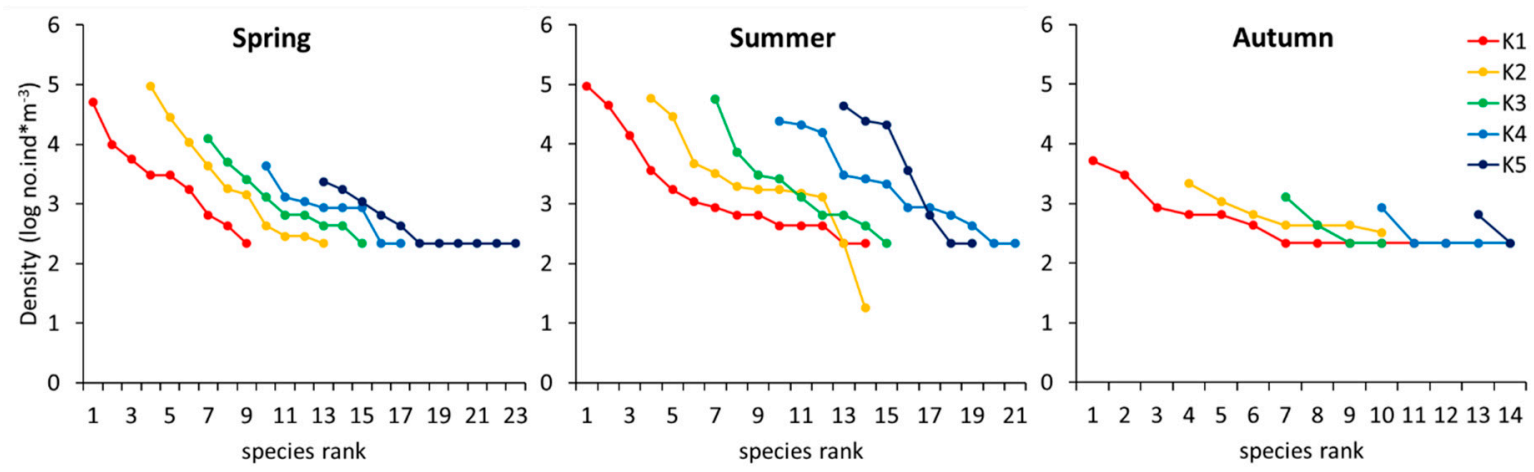

Figure 2. Rank-abundance curves of the seasonal rotifer assemblages at different distances (K1-K5) from the inflow point. (To decrease overlap, the starting positions of the individual curves were displaced by three positions). 


\subsubsection{Rényi Diversity Profiles}

In spring, according to the Rényi diversity ordering, the unequivocally most diverse site was K5 (Figure 3). The other four assemblages could not be unequivocally ordered. At small values of the scale parameter (emphasis on rare species), the order was $\mathrm{K} 2>\mathrm{K} 3>\mathrm{K} 1>\mathrm{K} 4$. Over most of the range, diversity increased with distance from the inflow $(K 4>K 3)$. There was little difference between the first two sites, K1 and K2. In summer, the five assemblages did not show any easily interpretable differences: $\mathrm{K} 4$ was unequivocally more diverse than $\mathrm{K} 2, \mathrm{~K} 4$ or $\mathrm{K} 5$, but mutual relationships with emphasis on rare species were chaotically different from values under higher influence of moderately common or dominant species. In autumn, both $\mathrm{K} 1$ and $\mathrm{K} 2$ were unequivocally more diverse than the communities at the other three sites, which could also be unequivocally ordered among themselves $(\mathrm{K} 4>\mathrm{K} 3>\mathrm{K} 5)$. $\mathrm{K} 1$ was more diverse than $\mathrm{K} 2$ only when rare species were influential $(0<\alpha<2)$. At $\alpha$ $\geq 2$ and thereafter, site $\mathrm{K} 2$ was the most diverse, and $\mathrm{K} 5$ the lowest (Figure 3).
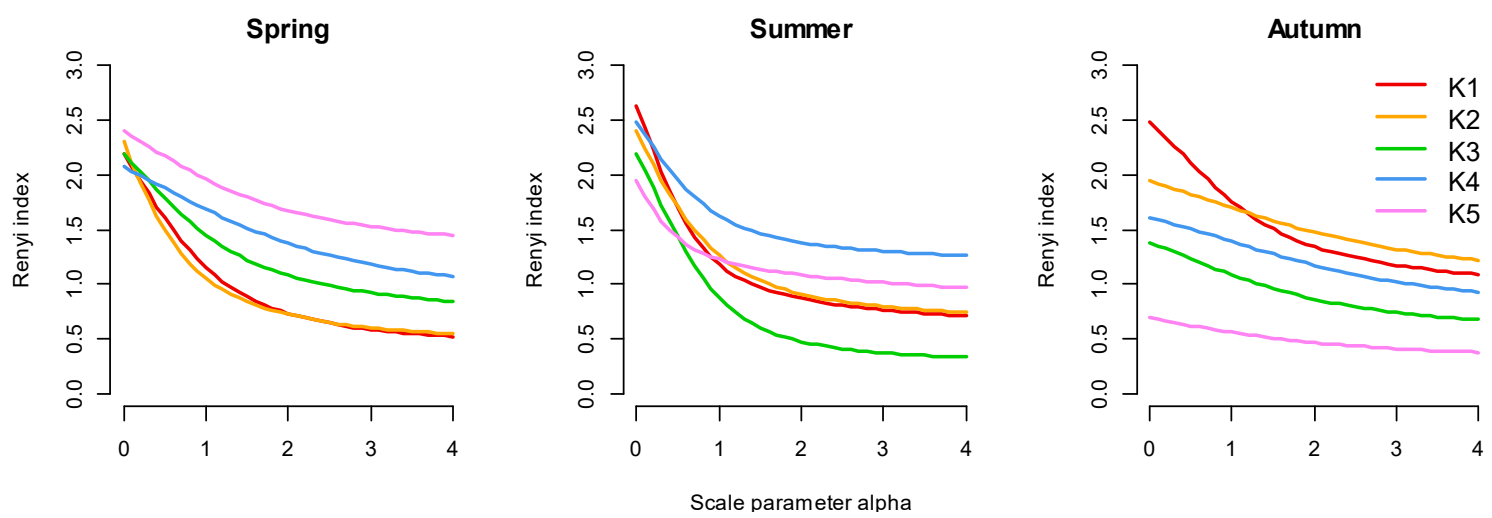

Figure 3. Rényi diversity profiles of the seasonal rotifer assemblages at different distances (K1-K5) from the inflow point in the Kákafok oxbow lake.

Regarding the seasonal biodiversity of the sampling points, a clear ordering can only be identified for K5. In this case, the spring > summer $>$ autumn order can be seen (Figure 4). At the point of inflow (K1), the initial, rare-species-influenced order of summer $>$ autumn $>$ spring changed to autumn $>$ summer $>$ spring at higher values of $\alpha$. Diversity in autumn was clearly higher than in spring. For K2, the order of summer $>$ spring $>$ autumn at $\alpha=0$ changed to autumn $>$ summer $>$ spring at $\alpha=1$ and at $\alpha=2$ : rotifer diversity in summer was clearly higher than in spring. At the third point (K3), the highest diversity was found in spring, but the order of summer $>$ autumn at $\alpha=0$ scale parameter reversed at $\alpha$ $=1$. At the fourth point (K4), rotifer diversity was clearly the lowest in autumn. The other two profiles crossed each other twice. At $\alpha=0$ rotifer diversity was greater in summer than in spring. This was reversed at $\alpha=1$ and turned back at $\alpha=2$, meaning that while there were more species in summer, these were rare, and the assemblage was dominated more by the common species. 

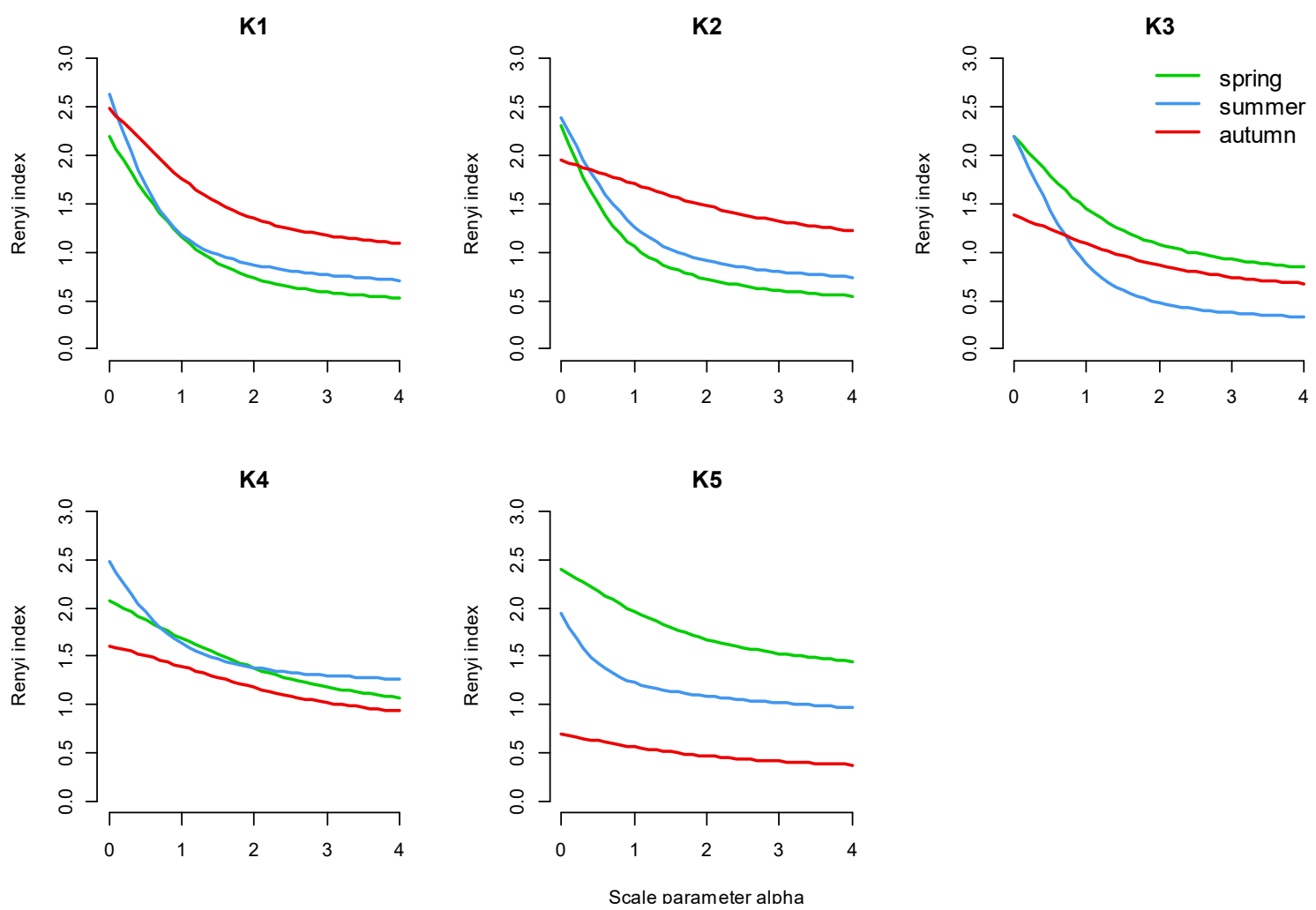

Figure 4. Rényi diversity profiles of rotifer assemblages in different seasons per distance (K1-K5) from the inflow point in the Kákafok oxbow lake.

\section{Discussion}

The survey indicated a species-rich rotifer fauna with 26 species ( 2 identified only to genus level). An earlier survey [33] found 13 and 8 species in the adjacent, protected Aranyos and Borza oxbow lakes, respectively, and 14 species in the similar oxbow lake of Dán-zug. In the Hármas-Körös, the parent river of the Kakafok oxbow, a survey conducted 25 years ago found 65 species [50], but 10 species present in the Kákafok oxbow lake were missing from that list. An extensive, 2 years survey in the oxbows near the Danube at Gemenc (between $1503 \mathrm{~km}$ and $1469 \mathrm{~km}$ ), found 71 rotifer taxa [51], 16 of which were in common with our survey. However, 8 found in ours $(30 \%)$ were not present in the Danube, indicating the taxonomic distinctness between the Danube and the Tisza Rivers.

Most of the species found in the Kákafok oxbow lake were characteristic of oligo- and oligo/ $\beta$ mesosaprobic waters [17] except the Brachionus species that prefers contaminated, $\beta$ and $\beta / \alpha$ mesosaprobic water bodies [17]. The species we detected (Brachionus angularis, B. calyciflorus, B. diversicornis, B. falcatus, B. forficula, B. leydigi, B. nilsoni, B. quadridentatus, B. urceolaris and B. variabilis) typically occurred in summer, mainly at K1-K2 points, indicating the impact of the effluent water combined with favourable thermal conditions. We found more Brachionus spp. than in the two previous studies $[33,50]$, which mostly belonged to the $\beta$ mesosaprobic indicator group $[17,18]$. Species previously detected in the mother river are Brachionus angularis, B. bennini, B. falcatus, B. budapestiensis, B. calyciflorus, B. urceolaris and B. quadridentatus [50], and in the other three oxbow lakes Brachionus bidentata, B. quadridentatus and B. calyciflorus were found [33]. In our samples, the most common species and in most places (Brachionus calyciflorus) also belonged to this genus. Trophic conditions are related to saprobic ones $[52,53]$. These species are also indicators of trophic conditions [11-14,16]. A similar species is Trichocerca pusilla in the work of Berzins [11], Jarenefelt [13], Thunmark [14] and Pejler [16] which also appeared only sporadically at the point of influx in summer and autumn. Sladacek [18] suggested that we can deduce the trophic level from the quotient of Brachionus vs. Trichocerca species. 
However, we could not apply this parameter because Trichocerca spp. could only be detected twice, at the point of influence in summer and autumn. However, most Brachionus species can also be detected here.

Our initial hypotheses were only partially supported by the data. The diversity profiles provide more sophisticated and articulated results than the usual one-dimensional diversity indices [54,55]. In spring, as we expected, the biodiversity increased with increasing distance from the point of inflow, but after a summer transition period, the situation became partially reversed during autumn. There was no clear seasonal difference between the inflow point and the closest one, indicating that the effect of the effluent did not decrease at a distance of $500 \mathrm{~m}$. In most cases, (spring and autumn), and for rare species in summer, point $\mathrm{K} 3$ showed medium diversity, conforming to our hypothesis. By summer, this site became the one of the lowest diversities as a result of a few species reaching high abundance and dominating the assemblage. The third most distant point (K4) gave surprising results. While by the end of the study period it could be clearly ranked, in spring it became the second most diverse community when the influence of rare species diminished. Unexpectedly, even in summer, diversity at K4 point was significantly higher than nearer and farther from the influx point. The probable reason is the presence of several species at higher abundance, which possibly competed with each other, and none of them managed to dominate the assemblage, creating high evenness in the assemblage. The most distant point (K5) was the most diverse in spring and the least diverse in autumn. In summer, its rotifer diversity was not clearly different from those at the other points. Comparing the different sampling points, the decreasing abundance with increasing distance from the inflow was most often observed in Brachionus species, which are indicators of more saprobic waters [17]. At the point of aquaculture inlet (K1) and nearby (K2), Brachionus spp. showed greater dominance in the same species set, leading to a decrease of diversity in spring. The species pool reached its maximum in summer; however, due to the predominance of more saprobic species, it did not result in a clearly identifiable increase in diversity. In autumn, the number of species and individuals decreased at the more distant points, while at the point of inflow a relatively rich and abundant community emerged. The monthly sampling may capture seasonal trends; however, given that rotifer generation time (from hatching to maturity) is typically about $24 \mathrm{~h}$, monthly sampling likely missed changes in rotifer communities that occur on a shorter time scale. Nonetheless, our survey indicated that rotifer species richness was higher than previously documented.

Summarizing, we detected a seasonally different effect of the aquaculture effluent in the composition of the rotifer community of the Kákafok oxbow lake. This effect was strongest during spring and autumn. In summer, the differences in taxonomic diversity disappeared. According to our investigations at the beginning of the study period, around the nutrient-rich effluent the dominance of common species increased. The differences in dominance decreased but did not disappear in summer. In autumn, however, the extra nutrient inflow enabled the maintenance of a diverse community at the point of effluent inlet. The question rightly arises as to how other factors (biotic interactions, phylogenetic connections, etc.) may have influenced the results. In addition, other environmental factors that had not yet been examined may play a role, including competition with copepods and cladocerans and predation or food availability. Due to the presence of closely related and different saprobiotic indicator species, functional and phylogenetic analysis may provide additional information.

Supplementary Materials: The following are available online at http://www.mdpi.com/2073-4441/12/5/1300/s1, Table S1: The list of rotifer species of the sample sites (K1-K5) every season, and the calculated number of individuals in the Kákafok oxbow lake, 2016.

Author Contributions: Conceptualization, É.K., and K.Z.; methodology, F.T., G.L.L. and L.K.; software, F.T. and L.K.; validation, L.K.; formal analysis, F.T.; writing-original draft preparation, F.T.; writing-review and editing, L.K., K.Z., É.K., L.B.-N. and G.L.L.; visualization, L.K., T.F.; supervision, K.Z., L.K. and G.L.L.; project administration, F.T., G.L.L.; data analysis, F.T., L.B.-N., sampling, F.T., L.B.-N., zooplankton identification, K.Z. All authors have read and agreed to the published version of the manuscript. 
Funding: During evaluation, F.T. was a recipient of a Hungarian-Danish mobility internship supported by Campus Mundi scholarship program of the Hungarian Tempus Public Foundation and the Hungarian Ministry of Agriculture.

Acknowledgments: We thank Marco Ferrante for support in using R statistical software, John Beaver and two anonymous reviewers for their useful comments.

Conflicts of Interest: The authors declare no conflict of interest.

\section{References}

1. FAO. The State of World Fisheries and Aquaculture 2018-Meeting the Sustainable Development Goals; Food and Agriculture Organisation: Rome, Italy, 2018; Available online: http://www.fao.org/3/i9540en/19540EN.pdf (accessed on 3 May 2020).

2. Edwards, P. Aquaculture environment interactions: Past, present and likely future trends. Aquaculture 2015, 447, 2-14. [CrossRef]

3. Kerepeczki, É; Gál, D.; Szabó, P.; Pekár, F. Preliminary investigations on the nutrient removal efficiency of a wetland-type ecosystem. Hydrobiologia 2003, 506-509, 665-670.

4. Č́žžková, H.; Květ, J.; Comín, F.A.; Laiho, R.; Pokorný, J.; Pithart, D. Actual state of European wetlands and their possible future in the context of global climate change. Aquati. Sci. 2013, 75, 3-26. [CrossRef]

5. Carp, E. International Conference on the Conservation of Wetlands and Waterfowl. In Proceedings of the International Conference on the Conservation of Wetlands and Waterfowl, Ramsar, Iran, 20 January-3 February 1971; IWRB: Slimbridge, UK, 1972; p. 303.

6. Pinke, Z. Modernization and decline: An eco-historical perspective on regulation of the Tisza Valley, Hungary. J. Historical Geogr. 2014, 45, 92-105. [CrossRef]

7. Somogyi, S. Geographical and Ecological Effects of 19th Century River Regulations and Flood Control in Hungary; Geographical Research Institute, Hungarian Academy of Sciences: Budapest, Hungary, 2000. (In Hungarian)

8. Pálfai, I. Oxbows of Hungary; Hungarian Ministry of Transport and Water: Budapest, Hungary, 2001. (In Hungarian)

9. Duggan, I.C.; Green, J.D.; Shiel, R.J. Distribution of rotifers in North Island, New Zealand, and their potential use as bioindicators of lake trophic state. Rotifera 2001, IX, 155-164.

10. Caroni, R.; Irvine, K. The potential of zooplankton communities for ecological assessment of lakes: Redundant concept or political oversight? Biol. Environ. Proc. R. Irish Acad. 2010, 110B, 35-53. [CrossRef]

11. Berzins, B. Contribution to the limnology of South-eastern Latvia. Schweiz. Z. Hydrol. 1949, 11, $583-607$. (In German)

12. Lillieroth, S. On the consequences of artificial water level decrease for macrophytic and planktonic communities in the shallow lakes of the southern Swedish oligotrophic region: A study with particular attention to applied limnology. Acta Limnol. 1950, 3, 1-288. (In Germain)

13. Jarnefelt, H. Plankton as indicator of the trophic status of lakes. Ann. Acad. Sci. Fenn. (Ser. A) 1952, 18, 1-29. (In German)

14. Thunmark, S. Contribution to the sociology of freshwater plankton. An ecological-methodological study. Folia Limnol. Scand. 1945, 3, 1-66. (In German)

15. Pejler, B. Taxonomical and ecological studies on plankton Rotatoria from central Sweden. K. Svenska Vetensk Akad. Handl. 1957, 6, 1-52.

16. Pejler, B. Regional ecological studies of Swedish freshwater zooplankton. Zool. Bidrag. Fran. Upp. 1965, 36, 407-515.

17. Gulyás, P. COMECON Biological methods. Vizügyi Hidrobiol. 1983, 12, 163-216. (In Hungarian)

18. Sládeček, V. Rotifers as indicators of water quality. Hydrobiologia 1983, 100, 169-201. [CrossRef]

19. Ejsmont-Karabin, J. The usefulness of zooplankton as lake ecosystem indicators: Rotifer trophic state index. Pol. J. Ecol. 2012, 60, 339-350.

20. Ochocka, A.; Pasztaleniec, A. Sensitivity of plankton indices to lake trophic conditions. Environ. Monit. Assess. 2016, 188, 622. [CrossRef]

21. Finlay, B.J. Global dispersal of free-living microbial eukaryote species. Science 2002, 296, 1061-1063. [CrossRef]

22. Fenchel, T.; Finlay, B.J. The ubiquity of small species: Patterns of local and global diversity. Bioscience 2004, 54, 777-784. [CrossRef] 
23. Segers, H.; de Smet, W.H. Diversity and endemism in Rotifera: A review, and Keratella Bory de St Vincent. Biodivers. Conserv. 2008, 17, 303-316. [CrossRef]

24. Dumont, H.J. Biogeography of rotifers. Dev. Hydrobiol. 1983, 14, 19-30. [CrossRef]

25. Segers, H. Global biodiversity of rotifers (Rotifera) in freshwater. Hydrobiology 2008, 595, 49-59. [CrossRef]

26. Wallace, R.L.; Snell, T.W.; Ricci, C.; Nogrady, N. Rotifera Biology, Ecology and Systematics; Backhuys Publishers: Leiden, The Netherlands, 2006.

27. Allan, J.D. Life history patterns in zooplankton. Am. Nat. 1976, 110, 165-180. [CrossRef]

28. Gannon, J.E.; Steinberger, R.S. Zooplankton (especially crustaceans and rotifers) as indicators of water quality. Trans. Am. Micros. Soc. 1978, 97, 16-35. [CrossRef]

29. Marbá, N.; Krause-Jensen, D.; Alcoverro, T.; Birk, S.; Pederson, A.; Neto, J.M.; Orfanidis, S.; Garmendia, J.M.; Muxika, I.; Borja, A.; et al. Diversity of European seagrass indicators: Patterns within and across regions. Hydrobiologia 2013, 546, 397-404.

30. Megyeri, J. Plankton studies on the River Tisza at Szeged. Hidrol. Köziemenyek 1955, 35, $280-292$. (In Hungarian)

31. Zsuga, K. The ecological conditions of the Cris/Körös catchment area on the basis of planktonic fauna. In The Criş/Körös River Valley: A Study of the Geography, Hydrobiology and Ecology of the River System and Its Environment; TISCIA Monograph Series; Sárkány-Kiss, A., Hamar, J., Eds.; Tisza Club \& Liga Pro Europa: Szolnok-Szeged, Hungary; Tirgu-Mures, Romania, 1997; Volume 2, pp. 135-152.

32. Zsuga, K. Long-term zooplankton investigations in the Hungarian section of the Körös catchment area. In The Criş/Körös River Valley: A Study of the Geography, Hydrobiology and Ecology of the River System and Its Environment; TISCIA Monograph Series; Sárkány-Kiss, A., Hamar, J., Eds.; Tisza Club \& Liga Pro Europa: Szolnok-Szeged, Hungary; Tirgu-Mures, Romania, 1997; Volume 2, pp. 153-164.

33. Gulyás, P. Rotatoria and crustacea studies in the surface waters of the Körös-Maros National Park. Crisicum 2000, 3, 111-139. (In Hungarian)

34. Rényi, A. On measures of entropy and information. In Proceedings of the 4th Berkeley Symposium on Mathematical Statistics and Probability, Berkeley, CA, USA, 30 June-30 July 1960; Neyman, J., Ed.; University of California Press: Berkeley, CA, USA, 1961; pp. 547-561.

35. Gliwicz, Z.M. Studies on the feeding of pelagic zooplankton in lakes with varying trophy. Ekol. Pol. 1969, $17 A, 663-708$

36. Odum, E.P. The Strategy of ecosystem development. Science 1969, 164, 262-270. [CrossRef]

37. Józsa, V.; Kozłowski, J.; Zróbek-Sokolnik, A.; Kozłowski, K.; Dynowski, P. Classification of the Oxbow Lakes of the Hármas-Körös River and Determination of Ways for Further Exploiting the Various Water Regions in the Light of the Water Framework Directive. In Proceedings of the "Environmental Engineering" 10th International Conference, Vilnius, Lithuania, 27-28 April 2017.

38. Tóth, F.; Berzi-Nagy, L.; Kerepeczki, É. Preliminary assessment of the most important water quality parameters of the Bikazugi Holt-Körös. In Proceedings of the 41st Meeting of Fisheries Science, Szarvas, Hungary, 14-15 June 2017; p. 52. (In Hungarian).

39. Tóth, F.; Kerepeczki, É.; Berzi-Nagy, L. Efficiency of an established wetland water treatment system based on renewable energy and its zooplankton production potential. In Proceedings of the 2nd Meeting of the Training Young Scientist Program, Szeged, Hungary, 14-15 December 2017; National Agricultural and Innovation Centre: Gödöllő, Hungary, 2018; pp. 35-44. (In Hungarian).

40. ISO. Water Quality_Determination of Nitrogen. Part 1: Method Using Oxidative Digestion with Peroxodisulfate; International Organization for Standardization: Geneva, Switzerland, 1997.

41. ISO. Water Quality-Determination of Phosphorus-Ammonium Molybdate Spectrometric Method; International Organization for Standardization: Geneva, Switzerland, 2004.

42. ISO. Water Quality_Determination of Suspended Solids by Filtration through Glass-Fibre Filters; International Organization for Standardization: Geneva, Switzerland, 1997.

43. Bancsi, I. Identification keys for Rotifera I. In Vízügyi Hidrobiológia, 15; Országos Vízügyi Hivatal: Budapest, Hungary, 1986. (In Hungarian)

44. Bancsi, I. Identification keys for Rotifera II. In Vízügyi Hidrobiológia, 17; Országos Vízügyi Hivatal: Budapest. Hungary, 1988. (In Hungarian)

45. R-Forge, Welcome to Vegan-Community Ecology Package Project! Available online: http://vegan.r-forge.rproject.org/ (accessed on 18 March 2020). 
46. The R Project for Statistical Computing. Available online: http://www.r-project.org/ (accessed on 18 March 2020).

47. Whittaker, R.H. Dominance and Diversity in Land Plant Communities: Numerical relations of species express the importance of competition in community function and evolution. Science 1965, 147, 250-260. [CrossRef]

48. Southwood, T.R.E.; Henderson, P.A. Ecological Methods, 3rd ed.; Blackwell Science Ltd.: Oxford, UK, 2009.

49. Lövei, G.L.; Liu, W.; Guo, J.; Wan, F. The use of the Rényi scalable diversity index to assess diversity trend sin comparative and monitoring studies of effects of transgenic crops. J. Biosaf. 2013, 22, 43-50.

50. Gulyás, P.; Bancsi, I.; Zsuga, K.V. Rotatoria and Crustacean fauna of the Hungarian watercourses. Miscellinea Zool. Hung. Tomus 1995, 10, 21-47.

51. Schöll, K. Diversity of planktonic rotifer assemblages in the water bodies of the Gemenc floodplain (Duna-Dráva National Park, Hungary). Biologia 2009, 64, 951-958. [CrossRef]

52. Kolkwitz, R. Plant Physiology, 3rd ed.; VEB Gesellschaft: Jena, Germany, 1935. (In Germain)

53. Sládeček, V. Relation of saprobic to trophic levels. Int. Ver. Theor. Angew. Limnol.: Verh. 1978, 20, 1885-1889. (In Germain)

54. Lövei, G.L. Generalised entropy indices have a long history in ecology-a comment. Community Ecol. 2005, 6, 245-247. [CrossRef]

55. Tóthmérész, B. Comparison of different methods for diversity ordering. J. Veg. Sci. 1995, 6, $283-290$. [CrossRef]

(C) 2020 by the authors. Licensee MDPI, Basel, Switzerland. This article is an open access article distributed under the terms and conditions of the Creative Commons Attribution (CC BY) license (http://creativecommons.org/licenses/by/4.0/). 